\title{
PENGARUH TINGKAT SUKU BUNGA, INFLASI DAN PERTUBUHAN GROSS DOMESTIC PRODUCT TERHADAP JUMLAH UANG BEREDAR DI TIMOR-LESTE
}

\author{
José Augusto Maria ${ }^{1}$ \\ I B. Panji Sedana ${ }^{2}$ \\ Luh Gede Sri Artini ${ }^{3}$ \\ ${ }^{1,2,3}$ Fakultas Ekonomi dan Bisnis, Universitas Udayana (Unud), Bali, Indonesia \\ Email: jose.maria@bancocentral.tl
}

\begin{abstract}
ABSTRAK
Peningkatan jumlah uang beredar merupakan tolak ukur salah satu pertumbuhan ekonomi suatu Negara. Uang memiliki peranan strategis dalam perekonomian terutama karena fungsi utamanya sebagai media untuk bertransaksi, sehingga pada awalnya sering diartikan menjadi satuan yang dapat diterima umum sebagai alat pembayaran (Iskandar Putong, 2007). Lokasi penelitian dilakukan pada Bank Sentral Timor-Leste dan laporan tahunan IMF dan Bank Dunia periode 2004 - 2013. Metode pengumpulan data dengan menggunakan data kuantitatif. Hasil yang didapat dalam penelitian dianalisa variabel - variabel menggunakan analisis Regresi Berganda dengan menggunakan program SPSS. Hasil penelitian menunjukkan dari ketiga variabel yang digunakan yaitu tingkat suku bunga, laju inflasi dan Gross Domestic Product yang hanya suku bunga dan inflasi yang berpengaruh negatif singnikan terhadap jumlah uang beredar, ini berarti Bank Sentral jika mengurangi jumlah uang yang beredar di Timor-Leste bisa dilakukan dengan meningkat suku bunga bank dan kebijakan fiskal pemerintah.
\end{abstract}

Kata kunci: Suku Bunga, Inflasi, Gross Domestic Product dan Jumlah Uang Beredar.

\begin{abstract}
The increasing of the money supply is a measure one of the economic growth of a country. Money has a strategic role in the economy, especially since its main function as a medium for transactions, so that at first is often translated into a common unit that can be accepted as means of payment (Putong Iskandar, 2007). The location of the research conducted at the Central Bank of East Timor has referred on the annual reports of the IMF and World Bank with the period $2004-$ 2013. The collect method analysis data is using the quantitative data. The results obtained in the studies analyzed variables using the multiple regression analysis program SPSS. The results showed that use of the three variables, namely interest rates, inflations and Gross Domestic Products is only the interest rate and inflation is significant negative effect on the money supply, this means that if the central bank reduces the amount of money circulating in East Timor can be done with rising interest rates and government fiscal policy.
\end{abstract}

Keywords: Interest Rate, Inflation, Gross Domestic Product and Money Supply. 
José Augusto Maria, I B. Panji Sedana, dan Luh Gede Sri Artini. Pengaruh Tingkat Suku...

\section{PENDAHULUAN}

Uang memiliki peranan strategis dalam perekonomian terutama karena fungsi utamanya sebagai media untuk bertransaksi, sehingga pada awalnya sering diartikan bahwa uang adalah sesuatu yang dapat diterima umum sebagai alat pembayaran. Sejalan dengan perkembangan perekonomian, fungsi uang yang semula hanya sebagai alat pembayaran berkembang menjadi alat satuan hitung dan sebagai alat penyimpan kekayaan. Uang beredar merupakan jumlah uang dikeluarkan secara resmi baik oleh Bank Sentral dalam bentuk uang kartal maupun uang giral dan uang kuasi yang dikeluarkan oleh Bank Umum menurut Iskandar Putong 2007.

Tingkat suku bunga tidak mempengaruhi peranan dalam menentukan jumlah uang yang ditawarkan pada waktu tertentu. Sendangkan permintaan uang adalah permintaan agregat, yaitu keseluruhan permintaan uang dalam perekonomian yang merupakan permintaan uang untuk transaksi, berjaga-jaga dan spekulasi, Soekirno 2001. Uang beredar sering dikaitkan dengan suku bunga, pertumbuhan Gross Domestic Product tingkat inflasi. Jumlah uang beredar yang terlalu banyak dapat mendorong kenaikan harga barang-barang secara umum akan menimbulkan inflasi. Apabila jumlah uang beredar terlalu sedikit maka kegiatan ekonomi akan menjadi lebih lambat. Berdasarkan hal tersebut maka jumlah uang beredar perlu diatur agar sesuai kapasitas ekonomi.

Timor-Leste memilih sistem moneter yang stabil dengan mata uang yang bebas adalah mata uang dolar Amerika (United State Dollar (USD) of America dan Coin Timor-Leste (Centavos) menjadi mata uang resmi sesuai Decree-Law 
No. 20/2003. Konstitusi Timor-Leste pasal 143 tahun 2002 yang mengatur tentang fungsi dan tugas Bank Sentral Timor-Leste. Bank Sentral secara resmi didirikan pada tanggal 13 September 2011 dengan UU No. 5/2011. Fungsi Bank Sentral sebelumnya adalah Banking and Payments Authority (2001-2011) dan Central Payments Office (2000-2001) dan lembaga-lembaga ini diciptakan oleh Administrasi Transisi Perserikatan Bangsa Bangsa di Timor-Leste ( UNTAET), yang mengelola negara dari Oktober 1999 sampai Mei 2002.

Salah satu kebijakan Bank Sentral dengan pemerintah Timor-Leste adalah menciptakan kondisi agar tersediannya kesempatan kerja, pertumbuhan ekonomi, dan stabilitas harga yang menjadi sasaran akhir yang ingin dicapai dapat direalisasi, namun dalam prakteknya seringkali dijumpai unsur-unsur yang kontradiktif atau tumpang tindih sehingga makin disadari akan pentingnya kebijakan moneter dengan sasaran tunggal. Salah satu sasaran tunggal yang saat ini menjadi model kebijakan moneter adalah penargetan inflasi (inflation targeting) yang telah banyak dilakukan oleh negara-negara maju dan saat ini dilakukan oleh pemerintah Timor - Leste, Antonio Serra 2012.

Dow dan saville (Insukindro, 2003) menyebutkan dua tipe kebijakan moneter yaitu berupa pengelolaan permintaan (demand management) dan target atau sasaran moneter (monetary tergety). Jenis kebijakan yang pertama dimaksudkan untuk mengendalikan jumlah uang beredar, sedangkan kebijakan kedua dilakukan mengendalikan inflasi dengan cara mengelolah permintaan agregat pada aktivitas yang tidak mendorong inflasi (non inflationary level). 
Tipe kebijakan tersebut ditenpuh oleh Timor-Leste dengan menempuh kebijakan tingkat suku bunga mengikuti suku bunga Amerika yang rendah untuk mengendalikan inflasi walaupun konsekuensinya adalah penurunan investasi yang dratis. Kebijakan ini dilakukan sejak tahun 2005 ketika secara global minyak dunia mengalami kenaikan harga sekitar dua kali lipat dari harga sebelumnya yang menyebabkan terjadinya inflasi yang tinggi. Berdasarkan perubahan global tersebut sedikit demi sedikit Banco Central de Timor-Leste (BCTL) menetapkan suku bunga mengikuti flutuasi Amerika dengan menurunkan tingkat suku bunga (BCTL Rate) yang mencapai angka penurunan sebesar 2.8 basis poin dari Desember 2004 sampai Desember 2007 yang menyebabkan BCTL rate menjadi 1.3\% pada Desember 2008. Kondisi ini memberikan pengaruh pada tingkat bunga yang diberlakukan pada bank-bank umum, yakni kalau pada tahun 2011 untuk tingkat bunga 3 bulanan rata-rata 1.1 persen sampai pada akhir 2013.

Kebijakan pemerintah tentang target inflasi memiliki keunggulan sasaran yang lain terhadap jumlah uang beredar, karena kebijakan ini dipusatkan pada fenomena domestik, penentuan sasaran yang lebih jelas dan sederhana, tidak tergantung pada hubungan antara uang dan inflasi. Dengan menggunakan model kebijakan ini maka inflasi di Timor-Leste dapat dikendalikan, namun kebijakan ini memiliki dua kelemahan yaitu: pertama kelemahan dalam pencapaian sasaran karena ada unsur waktu (time lag), sehingga sulit menentukan efektivitas kebijakan yang dikeluarkan.

Hal ini sangat berbeda dengan kebijakan pengelolaan jumlah uang beredar yang memiliki efek yang lebih cepat sehingga efektivitas dapat segera diketahui. 
Kedua, dapat menyebabkan terjadinya fenomena fluktuasi keluaran (output) yang membawa implikasi pada sektor riil, dimana untuk tujuan menahan inflasi harus dengan meningkatkan suku bunga yang pada akhirnya mengorbankan sektor riil, sehingga investasi menurun dan keluaran (output) juga menurun.

Di Negara Timor-Leste, harga-harga barang dan jasa selama tahun 2012 mengalami tekanan yang lebih berat dibadingkan dengan tahun sebelumnya. Kondisi itu tercermin dari kondisi inflasi pada tahun 2008 mencapai 11.6\% dan 2011 mencapai 17.4\% lebih tinggi dibandingkan tahun 2012 sebesar 11.8\%, kemudian pada lima tahun sebelumnya 2007 kondisi inflasi mencapai 8.6\%.

Hal mendasar dan penting dalam merespon kondisi seperti ini adalah bagaimana kebijakan moneter atau fiskal yang diterapakan bisa efektif dan tidak berakibat buruk bagi perekonomian. Pada saat laju pertumbuhan inflasi meningkat cukup tinggi, pemerintah harus merespon melalui penerapan kebijakan atau fiskal sesuai dengan sasaran yang dituju dalam perekonomian. Artinya tingkat inflasi harus dikendalikan pada tingkat pertumbuhan yang relatif tepat. Pengedalian ini harus bersifat hati - hati dan tidak secara dramatis sehingga menghindari kebijakan yang overdone, karena bisa menyebabkan stagnasi. Suatu kondisi yang tentunya tidak bermanfaat, karena penurunan tingkat pertumbuhan output aggregate (pendapatan nasional) non petroleum.

Seberapa jauh dampak inflasi dalam perekonomian, akan sangat tergantung dari tingkat keparahan inflasi yang terjadi. Tingkat inflasi yang ditandai dengan menjoloknya harga secara umum tidak selalu berdampak negatif. Sering kali kenaikan harga yang tidak terlalu tinggi mempunyai pengaruh positif, terutama 
terhadap iklim investasi. Kenaikan harga seperti ini pada dasarnya merupakan insentif bagi pengusaha untuk melakukan kegiatan produksinya. Kebijakan ekonomi moneter Timor-Leste dapat disetujui dengan efek positif yang dapat tercapai secara maksimal dengan inflasi ringan dibawah 10\% (Antonio Serra, 2012). Aspek penting yang perlu dicerminkan dalam mencegah tingkat keparahan inflasi adalah mengidentifikasi penyebab terjadinya inflasi. Dalam dimensi ekonomi makro inflasi bisa dipicu dari sisi permintaan aggregate atau penawaran aggregate.

Sasaran dari kebijakan moneter adalah pengaturan jumlah uang beredar melalui instrumen politik pasar terbuka dan politik fiskal pemerintah. Penggunaan instrumen ini dapat menekan volume jumlah uang beredar dalam batasan tertentu sehinggan tingkat inflasi bisa mencapai target yang diinginkan. Pengendalian inflasi melalui kebijakan fiskal dilakukan melalui pengaturan pengeluaran pemerintah (government expenditure) dan perpajakan. Pengendalian melalui instrument perpajakan secara langsung mempengaruhi permintaan total, sehingga akan mempengaruhi harga.

Pengaruh terhadap harga disebabkan oleh kenaikan output, karena produsen cenderung meningkatkan volume produksi untuk memperoleh keuntungan yang lebih besar. Kenaikan output yang lebih besar pada akhirnya mengakibatkan akses supply. Efek balik yang diperoleh akan menyebabkan harga kembali turun sehingga memperkecilkan tingkat inflasi. Upaya untuk mewujudkan stabilitas perekonomian makro akibat terpaan krisis politk internal dan keuangan global 
sejak pertengahan tahun 2008 adalah satu indikasi nyata melambungnya tingkat inflasi yang makin tinggi saat itu.

Situasi ini hampir tak terkendali sehingga memperburuk kinerja sektor riil dan jasa dalam menjalankan aktivitasnya. Bahkan sangat menimbulkan kekhawatiran terjadinya stagnasi ekonomi yang makin meluas. Fenomena tingkat inflasi nasional mamasuki tahun 2012 menunjukan kecenderungan yang menurun. Kodisi ini dikarenakan terjadinya penguatan nilai tukar US Dollars dan ekspektasi inflasi. Pada akhir tahun 2011 terjadi peningkatan inflasi akibat kebijakan pemerintah yang menganut pasar bebas sehingga mempengaruhi harga dan pendapatan seperti: kenaikan harga bahan bakar minyak (BBM), tarif dasar telepon dan tarif listrik (TDL). Situasi ini memicu peningkatan harga barang dan jasa karena didorong oleh kenaikan faktor biaya (cost push) dan ekspektasi inflasi. Berdasarkan perkembangan tingkat inflasi menunjukan bahwa fenomena inflasi sangat dipengaruhi oleh sejumlah faktor yang berkaitan dengan kondisi dan kebijakan makro ekonomi. Kebijakan moneter menurut Putong (2003) yang dilakukan pemerintah secara teoritis dibagi menjadi dua (2), yaitu:

1) Kebijakan kuantitatif, yaitu kebijakan yang terkait dengan upaya-upaya untuk mempengaruhi jumlah uang beredar dan pengedalian suku bunga.

2) Kebijakan kualitatif, yaitu kebijakan yang sifatnya non intervensi dan lebih banyak menekankan pada keadaan pihak perbankan.

Secara teoritis besar kecilnya peredaran uang sangat tergantung dari pengeluaran pemerintah. Apabila pemerintah melakukan kebijakan yang ekspansif, maka pemerintah akan melakukannya dengan memperbesarkan jumlah 
José Augusto Maria, I B. Panji Sedana, dan Luh Gede Sri Artini. Pengaruh Tingkat Suku...

uang beredar, baik dengan cara memperbesar pengeluarannya (kebijakan fiskal) maupun dengan cara mengimpor uang kertas baru dan mencetak uang baru (kebijakan moneter). Apabila pemerintah melakukan kebijakan kontraksi, maka pemerintah akan mengurangi jumlah uang yang beredar dengan cara mengurangi pengeluaran belanja negara, meningkatkan pungutan pajak serta menarik peredaran uang. Kebijakan tersebut sepenuhnya ditentukan oleh pemerintah, maka jumlah uang beredar bersifat otonomi, yaitu tidak ada satu variabel yang dapat mengubahnya.

Perkembangan angka-angka indikator makro di Timor-Leste mengalami fluktuasi, dimana perkembangannya sangat dipengaruhi oleh kondisi ekonomi yang berlangsung pada saat itu. Perkembangan ekonomi yang paling ekstrim terjadi ketika Timor-Leste mengalami krisis politik internal dan keuangan global pada tahun 2006 yang kemudian berkembang menjadi krisis moniter tahun 2008 berlanjut tahun 20011, dan oleh karena tidak mampu ditanggulangi oleh pemerintah secara cepat pada akhirnya manjadi krisis multidimensional yang berlangsung paling cepat diantara negara-negara terkena krisis di Asia dan Pasifik.

Perkembangan tingkat suku bunga yang berlaku pada bank umum sebelum krisis militer/politik tahun 2006 serta dilajutkan krisis keuangan tahun 2008 berkisar pada 2.5 and 1.6 persen sampai 1.3 persen, namun pada saat krisis keuangan berkisar pada angka antara 1,6 persen sampai terrendah 1.1 persen. Perkembangan tingkat inflasi yang senderung mengalami perkembangan antara 8.6 persen sampai 11.6 persen pada krisis politik internal sedangkan pada masa belum krisis keuangan dan 2.8 persen sampai 9.2 persen pada saat krisis 
keuangan. Perkembagan Gross Domestic Product (GDP) sebelum krisis militer/politik tahun 2006 dan krisis keuangan tahun 2008 berkisar antara 143.11 - 186.16 juta dolar, namun pada saat kedua krisis terjadi berkisar antara 149.67 204.27 juta dolar.

Kesenderungan yang terjadi pada jumlah uang beredar dalam arti luas (M2) dimana pada masa sebelum krisis militer/politik dan krisis keuangan berkisar pada 61.41 juta dolar sampai dengan 99.89 juta dolar, namun pada saat kedua krisis terjadi berkisar pada angka 192.66 juta dolar sampai dengan 500.25 juta dolar pada tahun 2013.

Identifikasi variabel-variabel penentu dari permintaan uang dalam kajian yang dilakukan mencakup uang kartal (currency), narrow money (M1) dan broad money (M2). Banyak analis diskon M2 sebagai peninggalan karena perbankan struktural berubah untuk memberikan tabungan lebih fleksibel. Faktor yang mempengaruhi permintaan uang masyarakat adalah suku bunga (suku bunga deposito), Gross Domestic Product (GDP) dalam negeri, dan inflasi domestik. Variabel lain yang dijadikan sebagai penentu permintaan uang antara lain: Gross Domestic Income (GDI), interest rate differential. Price Simon dan Insukindro (1994), mencoba untuk menganalisis komponen permintaan uang dalam arti sempit (money stock) dengan menggunakan teknik ekonometrik modern.

Bersadarkan latar belakang masalah dengan didukung data tersebut ternyata perubahan naik turunnya variabel- varibel tersebut mengalami flutuasi, namun kelihatannya kecenderugan awal menunjukkan bahwa krisis politik internal dan keuagan memiliki peranan yang nyata terhadap fluktuasi variabel- 
José Augusto Maria, I B. Panji Sedana, dan Luh Gede Sri Artini. Pengaruh Tingkat Suku...

variabel tersebut, maka menarik untuk melakukan penelitian secara lebih mendalam untuk mengetahui lebih jauh mengenai pengaruh tingkat suku bunga, inflasi dan GDP terhadap jumlah uang beredar di Timor-Leste.

Tujuan dilakukannya penelitian ini adalah sebagai berikut:

1) Untuk mengetahui signifikansi pengaruh tingkat Suku Bunga terhadap jumlah uang beredar.

2) Untuk mengetahui signifikansi pengaruh laju inflasi terhadap jumlah uang beredar.

3) Untuk mengetahui signifikansi pengaruh GDP berpengaruh signifikan terhadap jumlah uang beredar.

\section{KAJIAN PUSTAKA}

Uang adalah segala sesuatu yang dapat dipakai sebagai alat pembayaran yang sah. Untuk dapat dipakai sebagai alat pembayaran yang sah, maka uang harus memenuhi tiga fungsi berikut ini:

1) Sebagai satuan pengukur nilai atau satuan hitung.

2) Sebagai alat pertukaran.

3) Sebagai alat penimbun atau penyimpan kekayaan.

\section{Mekanisme uang beredar di Pasar}

Mekanisme uang beredar bergerak melalui jalur Bank Sentral Timor-Leste yang berfungsi sebagai pencetak uang atau pengadaan uang.

\section{Bank Sentral}

Bank Sentral adalah lembaga Negara yang mempunyai wewenang untuk memgeluarkan alat pembayaran yang sah dari suatu Negara, merumuskan dan malaksanakan kebijakan moneter, mengatur dan menjaga kelancaran sistem 
pembayaran, mengatur dan mengawasi perbankan serta menjalankan fungsi sebagai linder of the last resort. Bank Sentral yang dimaksud adalah Banco Central de Timor-Leste. Banco Central de Timor-Leste adalah lembaga Negara yang independen dalam melaksanakan tugas dan wewenangnya, bebas dari campur tangan pemerintah atau pihak lain, yang tujuannya adalah untuk mencapai dan memelihara kestabilan nilai Dolar.

\section{Bank Umum}

Bank umum merupakan bank yang melaksanakan kegiatan usaha secara konvensional dalam kegiatannya memberikan jasa lalu lintas pembayaran. Bank umum mempunyai banyak kegiatan. Adapun kegiatan-kegiatan bank umum yang utama antara lain :

1) Menghimpun dana dari masyarakat dalam bentuk giro, deposito, sertifikat deposito, dan tabungan;

2) Memberikan kredit;

3) Menerbitkan surat pengakuan utang;

4) Memindahkan uang, baik untuk kepentingan nasabah maupun untuk kepentingan bank itu sendiri;

5) Menerima pembayaran dari tagihan atas surat berharga dan melakukan perhitungan atau dengan pihak ketiga;

6) Menyediakan tempat untuk menyimpan barang dan surat berharga;

7) Melakukan penempatan dana dari nasabah ke nasabah lainnya dalam bentuk surat berharga yang tidak tercatat di bursa efek.

\section{Nilai Uang Beredar di Pasar}


Peredaran nilai uang nominal yang disediakan oleh BCTL adalah mata uang dolar Amerika dan uang logam Centavos yang menjadi nilai tukar resmi di Timor-Leste. Kedua mata uang tersebut masing-masing memiliki enam pecahan yaitu untuk uang kertas USA dengan nilai $\$ 100, \$ 50, \$ 20, \$ 10, \$ 5$ dan $\$ 1$ sedangkan Centovos Timor-Leste terdiri dari pecahan 100, 50, 25, 10, 05 dan 1 cents. Koversi nilai tukar antara Dolar Amerika dengan Centavos Timor-Leste memiliki perbandingan yang sama yaitu $\$ 1=\$ 1$ Centavos.

\section{Teori Kuantitas Uang}

Ada berapa teori mengenai kuantitas uang diantaranya adalah teori dari Irving Fisher dan teori dari Mashab Cambridge yang dipelopori oleh Marshall dan Piqou, yang akan dijelaskan berikut ini.

Teori persamaan pertukaran dari Irving Fisher. Menurut Fisher perubahan jumlah uang yang beredar $(\mathrm{M})$ berbanding lurus dengan perubahan harga-harga $(\mathrm{P})$, sehingga dalam bentuk persamaan dapat ditulis:

$$
\mathrm{MV}=\mathrm{PT}
$$

Keterangan:

$\mathrm{M}=$ Jumlah Uang yang beredar (M1)

$\mathrm{V}=$ Kecepatan peredaran uang (Velocity circulation of money) yaitu banyaknya uang yang berpindah tangan dari satu tangan ke tangan orang lain.

$\mathrm{P}=$ Tingkat harga umum

$\mathrm{T}=$ Jumlah produksi barang jadi maupun setenggah jadi (dengan asumsi $\mathrm{V}$ dan T konstan).

Berdasarkan persamaan tersebut maka nilai pendapatan nasional dari $\mathrm{P}$ x $\mathrm{T}$ adalah lebih besar dari nilai $\mathrm{P} \times \mathrm{Q}$, karena $\mathrm{T}$ mencakup barang jadi dan setenggah jadi dengan harganya masing-masing. Persamaan tersebut juga dapat ditulis: $\mathbf{M}=$ 
$\mathrm{PT} / \mathrm{V}$ artinya bila $\mathrm{M}$ meningkat sebesar 5 persen, maka $\mathrm{P}$ juga akan meningkat sebesar 5 persen, atau untuk menurunkan tingkat harga sebesar 5 persen, maka jumlah uang beredar juga harus diturunkan sebesar 5 persen.

Teori sisa tunai (cash balance theory) dari Alfred Marshall. Alfred Marshall merupakan orang pertama dari Mashab Cambridge yang menerangkan teori kuantitas uang dan meneliti hubungan antara jumlah uang beredar dengan tingkat harga secara umum (inflasi). Menurut Marshall banyaknya uang yang beredar dimasyarakat sebenarnya tidak secara keseluruhan mencakup uang yang dimiliki masyarakat, karena masih ada sebagian yang dipegang secara tunai (k), maka persamaan dasar teori adalah:

$$
\mathrm{M}=\mathrm{k} \text { PT atau } \mathrm{M}=\mathrm{k} \text { PY }
$$

\section{Keterangan :}

$\mathrm{M}=$ jumlah uang yang beredar

$\mathrm{k}=$ adalah besarnya uang tunai yang dipegang oleh masyarakat yang sebanding denga pendapatannya.

$\mathrm{P}=$ adalah harga-harga umum.

$\mathrm{T}$ atau $\mathrm{Y}=$ adalah jumlah produksi barang dan jasa baik berupa produk jadi maupun produk setengah jadi.

Menurut Robert J. Gordon dalam bukunya Macro Economics (Gordon, 2000), bahwa pengaruh perubahan tingkat suku bunga terhadap tingkat ouput nasional sangat tergantung pada permintaan pasar barang dan permintaan pasar uang. Kurve permintaan pasar barang dan pasar uang yang lebih curam akan menyebabkan perubahan tingkat bunga yang labih besar tidak elastis terhadap perubahan output, sementara bentuk kurve permintaan pasar barang dan pasar uang yang lebih landai akan menyebabkan elastisitas perubahan tingkat suku bunga terhadap output menjadi besar.

\section{Pengertian Tingkat Suku Bunga}


José Augusto Maria, I B. Panji Sedana, dan Luh Gede Sri Artini. Pengaruh Tingkat Suku...

Tingkat suku bunga yang diberlalukan sektor perbankan mengikuti pedoman tingkat bunga yang ditentukan oleh Banco Central Timor-Leste dimana mengikuti suku bunga yang ditetapkan oleh Banco Central Amerika.

Bank sentral rate merupakan wewenang Banco Central Timor-Leste dalam melaksanakan fungsinya sebagai banknya bank. Penurunan tingkat suku bunga Banco Central Timor-Leste selanjutnya akan menjadi pedoman bagi industri perbankan untuk menurunkan tingkat suku bunganya, sehingga diharapkan kredit yang disalurkan ke masyarakat akan meningkat secara signifikan. (Nasution,1998). Demikian juga investasi menurut teori klasik merupakan fungsi dari tingkat suku bunga, semakin tinggi tingkat suku bunga maka semakin kecil minat masyarakat untuk melalukan investasi, sebab keuntungan yang diperolaeh dari tingkat suku bunga akan lebih besar dibandinkan dengan

\section{Pengaruh Suku Bunga Terhadap Jumlah Uang Beredar}

Pengaruh perubahan suku bunga terhadap output nasional sangat tergantung pada permintaan pasar barang dan permintaan pasar uang (Gordon, 2000). Pada permintaan pasar barang dan pasar uang yang lebih curam akan menyebabkan perubahan tingkat suku bunga yang labih besar dan tidak elastis terhadap perubahan output, sementara bentuk permintaan pasar barang dan pasar uang yang lebih senderung akan menyebabkan perubahan tingkat suku bunga terhadap output.

Kenaikan suku bunga pada umumnya berpengaruh terhadap penurunan jumlah uang beredar di bank dan sebaliknya penurunan suku bunga bank akan mendorong peningkatan jumlah uang beredar. Permintaan prouduk sangat terkait dengan mendesaknya kebutuhan akan jumlah uang beredar, sehingga 
tingkat suku bunga yang berlaku tidak menjadi masalah dalam jumlah uang beredar.

\section{Pengaruh Inflasi Terhadap Jumlah Uang Beredar}

Inflasi adalah suatu keadaan dimana terdapat kenaikan harga umum secara terus menerus, bukan kenaikan atau dua macam barang saja, melainkan kenaikan harga dari sebagian besar barang dan jasa, dan juga bukan hanya terjadi satu atau dua kali kenaikan harga, melainkan secara terus menerus (Suparmoko, 2000). Untuk mengetahui tingkat inflasi, biasanya dipergunakan indeks harga, indeks harga yang paling banyak digunakan adalah indeks biaya hidup yang sudah mencakup 62 macam barang, yang selanjutnya sudah diperbaiki menjadi indeks harga konsumen yang meliputi 150 macam barang. Macam barang dikelompokan menjadi makanan, sedang, perumahan, dan lain-lain.

Inflasi berdasarkan parah dan tidaknya dapat dibedakan menjadi 4 jenis:

1) Inflasi ringan, kurang 10 persen per tahun.

2) Inflasi sedang antara 10 sampai 30 persen per tahun.

3) Inflasi berat antara 30 sampai 100 persen per tahun.

4) Hiper inflasi, di atas 100 persen per tahun.

Inflasi yang ringan dapat mendorong perekonomian lebih baik yaitu melalui peningkatan pendapatan nasional sehingga membuat orang bergairah untuk bekerja menabung, maupun kegiatan investasi. Sementara hiper inflasi, keadaan perekonomian akan menurun tajam dan lesu, sehingga orang tidak bersemangat untuk bekerja, menambung, berproduksi, maupun investasi.

\section{Pengaruh Gross Domestic Product Terhadap Jumlah Uang Beredar.}


Perubahan ekonomi adalah kenaikan pendapatan nasional secara berarti (dengan meningkatnya pendapatan) dalam suatu periode perhitungan tertentu. Menurut Schumpeter (dalam Putong, 2003) pertumbuhan ekonomi adalah pertambahan output (pendapat nasional) yang disebabkan oleh pertambahan alami dari penduduk dan tabungan.

Dalam Pertumbuhan ekonomi suatu negara diartikan menjadi pembangunan ekonomi yang merupakan istilah bagi Negara yang telah maju dalam menyebut keberhasilan pembangunannya, sementara untuk Negara yang sedang berkembang disebut dengan istilah pembangunan ekonomi.

Kelemahan teori ini adalah pendapatan perkapita antar Negara sangat variatif, Negara miskin tidak memiliki tingkat pengembalian modal yang cepat, negara miskin tidak memiliki kemamuan meningkatkan pendapatan sebagaimana negara maju, sehingga asumsi-asumsi yang dipergunakan banyak bertentangan dengan kenyataan.

Teori pertumbuhan endogen (Gordon,2000) menekankan pada pentingnya peranan investasi fisik dan sumber daya manusia yang berasal dari Negara maju untuk mempercepat pertumbuhan Negara berkembang. Tanpa adanya bantuan dari Negara maju kepada Negara berkembang, maka proses peningkatan pertumbuhan ekonomi di Negara berkembangn akan mengalami hambatan.

Dalam journal of policy Modelin(2012) dikatakan bahwa pertumbuhan ekonomi nasional suatu Negara sangat dipengaruhi olah pengembangan control financial terutama dalam jangka menengah dan jangka pajang, karena itu control terhadap jumlah uang yang beredar sangat penting dalam mengedalikan tingkat 
pertumbuhan ekonomi. Tanpa kontrol yang baik maka proses pengedalian pertumbuhan akan sangat sulit dilakukan terutama gejolak inflasi yang tinggi sering menyebabkan instabilitas pertumbuhan ekonomi.

Pertumbuhan ekonomi yang lebih tepat diukur dengan menggunakan pertumbuhan pendapatan per kapita menurut adanya kenaikan GDP atau pendapatan nasional. Pertumbuhan GDP tersebut sangat ditentukan oleh berbagai faktor-faktor produksi yang dimiliki Negara tersebut. Pada umumnya terdapat hubungan yang positif antara jumlah dan kualitas faktor produksi dengan GDP (Suparmoko, 2000). Semakin banyak digunakan alat capital, tenaga kerja, sumber daya alam, dan teknologi cangih serta keadaan sosial yang mendukung pertumbuhan ekonomi, maka akan semakin tinggi pula GDP atau pendapatan nasional dari satu Negara, maka ada hubungan positif antara pertumbuhan ekonomi dengan jumlah uang beredar, dimana jumlah uang beredar terdiri dari uang beredar dalam arti luas (M2) dan uang beredar dalam arti sempit (M1) dimana M1 terdiri dari uang kartal dan uang giral sedangkan M2 terdiri dari M1 dan uang kuasi. Sementara besar kecilnya $\mathrm{M}$ sangat tergantung dari perilaku masyarakat sehubungan dengan tingkat pendapatan dan tingkat suku bunga yang berlaku di pasar. Perubahan ekonomi yang relative tinggi akan menyebabkan meningkatnya pendapatan masysrakat sehingga jumlah uang beredar juga akan mengalami peningkatan, terutama untuk tujuan M1.

Gross Domestik Product sebagai indikator tingkat kesehatan pertumbuhan ekonomi Negara, meliputi Konsumsi + Investasi + Pengeluaran Pemerintah + (Ekspor-Impor) apabila peningkatan suku bunga mampu mengangkat 
José Augusto Maria, I B. Panji Sedana, dan Luh Gede Sri Artini. Pengaruh Tingkat Suku...

pertumbuhan ekonomi maka Interest Rate (IR) perlu dinaikkan demikian juga sebaliknya.

Dalam konstes pertumbuhan ekonomi, suku bunga dan tingkat inflasi Timor-Leste tahun 2004 - 2013 memiliki hubungan signifikan dengan jumlah uang yang beredar pada M2 dan M1. Sementara besar kecilnya M sangat tergantung dari perilaku masyarakat Timor-Leste sehubungan dengan tingkat pendapatan dan tingkat suku bunga yang berlaku di pasar.

Penelitian yang oleh Luh Kade Dartrini pada tahun 2009, judul jumlah uang beredar dengan mengunakan model Regresi Berganda, dengan mengunakan data periode tahun 1992 - 2005. Penelitian tersebut bertujuan untuk mengetahui apakah terdapat mengaruh suku bunga, inflasi, GDP dan krisis ekonomi terhadap jumlah uang beredar, serta pengaruh variabel-variabel lainnya terhadap jumlah uang beredar baik secara langsung maupun tidak langsung melalui kebijakan moneter.

\section{Kerangka Berpikir Penelitian}

Keberhasilan pembangunan nasional sangat diperngaruhi oleh pembagunan ekonomi, sebab pembangunan ekonomi merupakan faktor utama dalam menggerakan pembangunan. Sedangkan pembagunan ekonomi sangat ditentukan oleh kondisi moneter yang relatif stabil, kondisi meneter yang stabil pada prinsipnya sangat ditentukan oleh kebijakan pemerintah yang dikeluarkan melalui Bank Sentral. Tujuan kebijakan moneter pada hakekatnya adalah menjaga stabilitas jumlah uang beredar dalam arti luas, sementara jumlah uang yang beredar sangat terkaitan dengan tingkat suku bunga, tingkat inflasi, pertumbuhan 
ekonomi nasional. Kenaikan tingkat suku bunga akan menurunkan jumlah uang beredar demikian juga sebaliknya, sedangkan peningkatan harga-harga umum akan menaikan jumlah uang beredar, demikian juga kenaikan pertumbuhan ekonomi nasional juga akan berdampak pada kenaikan jumlah uang beredar, sementara krisis keuangan dan politik/militer merupakan ganguan terhadap kinerja ekonomi nasional yang berampak pada kenaikan jumlah uang beredar.

Penelitian ini bertujuan menganalisis pengaruh variable-variabel makro terhadap jumlah uang beredar baik secara simultan maupun secara persial, sedangkan alat analisis Regresi Linear Berganda yang digunakan dalam analisis adalah mengunakan SPSS.

Sesuai dengan tujuan dan jumlah variabel yang teridentifikasi, maka dapat dibuat model hubungan antara Suku Bunga Bank (X1), Laju Inflasi (X2), Pertumbuhan GDP (X3) dengan Jumlah Uang Beredar (Y) di institusi Banco Central de Timor-Leste.

\section{Konseptual}

Jumlah uang beredar dalam suatu perekonomian pada saat tertentu dikatakan sebagai keseluruhan jumlah uang yang ditawarkan oleh otoritas meneter dalam hal ini Banco Central de Timor-Leste. Sehingga jumlah uang beredar tersebut bukanlah hanya jumlah uang yang diminta oleh masyarakat tetapi termasuk jumlah uang yang dibutuhka oleh pemerintah berupa uang kartal dan uang giral dan uang kuasi.

Jumlah uang beredar secara keseluruhan (aggregative) sangat ditentukan oleh faktor-faktor seperti tingkat suku bunga, tingkat inflasi, pertumbuhan Gross Domestic Product. Apabila tingkat suku bunga semakin meningkat maka jumlah 
uang beredar akan menurun, karena masyarakat akan lebih tertarik menyimpan uangnya di bank untuk mendapatkan pendapatan yang lebih tinggi dengan tingkat suku bunga yang tinggi.

Sedangkan inflasi memiliki pengaruh yang positif terhadap jumlah uang beredar, sebab dengan adanya inflasi berarti adanya peningkatan harga barang dan jasa secara menyeluruh dan terus menerus selama periode tertentu, sehingga diperlukan jumlah uang yang lebih banyak untuk memperoleh sejumlah kebutuhan barang dan jasa dalam jumlah yang sama dengan sebelumnya. Demikian juga pertumbuhan ekonomi memiliki pengaruh positif terhadap jumlah uang beredar, karena pertumbuhan ekonomi akan menyebabkan peningkatan pendapatan masyarakat, peningkatan pendapatan ini berarti juga akan meningkatkan jumlah uang yang beredar dimasyarakat. Sedangkan krisis ekonomi juga memiliki pengaruh positif terhadap jumlah uang beredar, krisis ekonomi yang ditandai dengan meningkatnya nilai valuta asing dan inflasi yang sangat tinggi tentu akan menyebabkan jumlah uang beredar yang juga semakin tinggi.

\section{Hipotesis}

Berdasarkan kajian teoritis dan empiris serta konsep penelitian seperti apa yang telah diuraikan sebelumnya, dapat dirumuskan hipotesis sebagai berikut:

1) Tingkat suku bunga secara simultan berpengaruh signifikan terhadap jumlah uang beredar di Timor-Leste.

2) Tingkat inflasi secara parsial berpengaruh terhadap jumlah uang beredar di Timor-Leste.

3) Pertumbuhan GDP secara parsial berpengaruh terhadap jumlah uang beredar di Timor-Leste 


\section{METODE PENELITIAN}

Variabel jumlah uang beredar (Y) merupakan variabel dependent yang dipengaruhi oleh variabel bebas tingkat suku bunga (X1), tingkat inflasi (X2) dan Pertumbuhan ekonomi/GDP (X3), namun dapat menjadi variabel yang dipenruhi eksogen bagi variabel jumlah uang beredar $\left(\mathrm{Y}_{\mathrm{t}}\right)$.

\section{Prosedur Pengumpulan Data}

Metode yang digunakan untuk pengambilan data dalam penelitian ini adalah data kuantitatif yang diperoleh dari sumber kedua. Dalam hal ini adalah Banco Central de Timor-Leste, Departemen pusat Statistik Timor-Leste, serta berbagai publikasi hasil penelitian dan literature penunjang. Data tersebut berupa jumlah uang yang beredar, tingkat suku bunga, inflasi dan pertumbuhan GDP secara berturut - turut dari tahun 2004-2013.

\section{Metode Analisis Data}

Metode analisis data yang dikumpulkan untuk menjawab permasalahan penelitian, dilakukan dengan menggunakan analisis kuantitatif dengan analisis kualitatif untuk menunjang analisis kuantitatif. Dalam penelitian ini akan digunakan dua (2) Model Linier Berganda dan model dengan Variabel Lag. Dengan penambahan variabel lag yaitu variabel jumlah uang beredar satu tahun sebelumnya (Yt-1) disebut model penyesuaian adaptif yang bertujuan untuk mendapatkan hasil taksiran regresi yang terbaik karena penelitian dengan analisis regresi berganda dengan estimasi satu (1) model seringkali mendapatkan hasil analisis yang tidak tepat bila dilihat dari kriteria goodness of fit $(\mathrm{R})$ dan kriteria 
José Augusto Maria, I B. Panji Sedana, dan Luh Gede Sri Artini. Pengaruh Tingkat Suku...

best linier unbiased estimator (BLUE). Analisis kuantitatif menggunakan alat analisis sebagai berikut:

1) Uji Asumsi Klasik

Uji Pelanggaran Asumi Klasik dengan menggunakan 4 (empat) jenis pengujian berikut (Agus Widarjono, 2005):

a) Uji Normalitas Data

Merupakan suatu pengujian yang bertujuan untuk menguji apakah dalam residual dari Model Regresi yang dibuat berdistribusi normal atau tidak. Model Regresi yang baik adalah yang memiliki distribusi residual yang normal atau mendekati normal. Dalam penelitian ini Uji Normalitas dilakukan dengan menguji normalitas residual dengan menggunakan uji Kolmogorov-Smirnov, yaitu dengan membandingkan distribusi komulatif relatif hasil observasi dengan distribusi komulatif relatif teoritisnya. Jika probabilitas signifikansi nilai residual lebih besar dari 0,05 berarti residual terdistribusi dengan normal.

b. Uji multikolinearitas yaitu untuk mengetahui adanya hubungan linier diatara variabel bebas, sebab hubungan ini akan menyebabkan model menjadi kurang bagus karena memiliki varian yang besar. Metode uji yang dipergunakan adalah dengan melihat angka Tolerance tidak mengandung multikol bila mendekati nol dan VIF tegak mengandung multikol bila seluruh nilainya tidak lebih dari 10 .

c. Uji Autokorelasi, untuk mengetahui adanya hubungan antar residual, munculnya gejala ini sebagai pelanggaran penting dalam asumsi dengan 
menggunakan metode ordinary least square (OLS). Metode yang digunakan adalah Durbin-Watson tes (tidak mengandung autokorelasi bila nilai $\mathrm{du}<\mathrm{d}<$ $4-\mathrm{du})$.

d. Uji Heteroskedastisitas, yaitu uji untuk mengetahui apakah residual mempunyai varian yang tidak konstan sehingga estimator tidak memenuhi kriteria best linear unbased estimator (BLUE). Metode yang dipergunakan adalah metode grafik (informal) yaitu dengan memeriksa pola residual (ui2) terhadap taksiran Yi, bila menunjukkan varian yang cenderung konstan dalam plot data grafik, maka tidak terjadi kasus heteroskedastisitas.

2) Analisis Regresi Berganda dengan variabel sebagai berikut:

Variabel terikat:

Yt = Jumlah uang beredar

Variabel bebas:

$\mathrm{X} 1 \mathrm{t}=$ Tingkat suku bunga

$\mathrm{X} 2 \mathrm{t}=$ Inflasi

$\mathrm{X} 3 \mathrm{t}=$ Pertumbuhan GDP

Yt-1 = Lag jumlah uang beredar (jumlah uang beredar satu tahun sebelumnya).

Model yang dipergunakan dalam penelitian ini adalah model berikut:

a) Model Linier Berganda

$$
Y t=\beta o+\beta 1 \times 1 t+\beta 2 \times 2 t+\beta 3 \times 3 t+e i \ldots(3.1)
$$

b) Model Semi Log

$\log -Y t=\beta o+\beta 1 \times 1 t+\beta 2 \times 2 t+\beta 3 \times 3 t+e i \ldots(3.2)$

c) Model dengan Variabel Lag 
Model dengan variabel lag adalah model penyesuaian adaptif yang sama dengan model Koyck (Widarjono, 2005: 233) berikut.

$Y t=\beta o+\beta 1 X 1 t-1+\beta 1 X 2 t-1+\beta 3 X 3 t-1+\beta 4 Y t-1+e i$

Untuk mendapat nilai sebaran yang lebih kecil dari nilai $\mathrm{Y}$ sehingga tidak menimbulkan bias dalam penaksiran regesi, selanjutnya nilai $\mathrm{Y}$ dalam perhitungan disesuaikan dengan membagi mengunakan angka 1,000. Variavel ini selanjutnya disebut variabel $\mathrm{M}$, sehingga model penaksiran menjadi:

$\mathrm{Mt}=\beta \mathrm{o}+\beta 1 \mathrm{X} 1 \mathrm{t}-1+\beta 2 \mathrm{X} 2 \mathrm{t}-1+\beta 3 \mathrm{X} 3 \mathrm{t}-1+\beta 4 \mathrm{X} 4 \mathrm{t}-1+\mathrm{ei}$

Keterangan:

$\beta o=$ intercept (konstanta), yang menunjukkan besarnya nilai $\mathrm{M}$ bila nilai seluruh variabel bebas masing-masing sama dengan nol.

$\beta 1=$ koefisien regresi variabel tingkat suku bunga $(\mathrm{X} 1 \mathrm{t})$

$\beta 2=$ koefisien regresi variabel inflasi $(\mathrm{X} 2 \mathrm{t})$

$\beta 3=$ koefisien regresi variabel pertumbuhan GDP (X3i).

$\beta 4=$ koefisien regresi variabel jumlah uang beredar satu tahun sebelumnya (Yt-1).

$\mathrm{Ei}=$ stokastic error term (variabel pengganggu).

Mt = jumlah uang beredar sabagai variabel terikat.

$\mathrm{X} 1 \mathrm{t}=$ tingkat suku bunga .

$\mathrm{X} 2 \mathrm{t}=$ inflasi

$\mathrm{X} 3 \mathrm{t}=$ pertumbuhan GDP.

Model yang baik adalah model yang memenuhi kriteria terbaik (goodness of fit),yaitu model yang memiliki nilai koefisien determinasi yang baik dan tidak 
mengandung unsur pelanggaran asumsi klasik (multikolinearitas, heteroskedastisitas, dan autokolerasi) atau memenuhi kriteria BLUE (Best Linier Unbased Estimator).

3) Analisis Determinasi (R2 ) Dan Uji F (F Tes)

Rumus yang dipergunakan adalah :

$\mathrm{R} 2=\mathrm{ESS} / \mathrm{TSS}$

Dimana : ESS adalah Explained of Sum Square dan TSS adalah Total of Sum Square.

Analisis ini bertujuan untuk mengetahui besarnya variasi variabel terikat yang dapat dijelaskan oleh variasi seluruh variabel bebas. Nilai koefisien determinasi berkisar antara 0 sampai dengan 1, semakin mendekati angka 1 semakin besar variasi variabel terikat yang dapat dijelaskan oleh variasi variabel bebas, yang berarti semakin baik model yang dipergunakan (goodness of fit).

Uji F dimaksudkan untuk mengetahui signifikansi pengaruh variabel bebas secara bersama-sama terhadap variabel terikat. Tahap-tahapan dalam uji $\mathrm{F}$ (Frequencies).

4) Uji Signifikansi koefisien regresi secara individual (Nachrowi, 2006), untuk mengetahui apakah koefisien regresi yang diperoleh dari hasil penaksiran memang signifikan (nyata). Rumus yang digunakan adalah sebagai berikut:

$$
\mathrm{t}=\frac{\wedge}{\operatorname{Se}\left(\beta_{\mathrm{i}}\right)}
$$


$\beta_{\mathrm{i}}=$ koefisien regresi yang diperoleh dari hasil penaksiran untuk masingmasing variabel bebas.

$\operatorname{Se}\left(\beta_{\mathrm{i}}\right)=$ standar error masing-masing estimator.

5) Analisis Standardized Coefficients Beta, analisis ini digunakan untuk mengetahui pentingnya masing-masing variabel independen secara relatif ( Ghozali,2005:34), dalam penelitian ini metode analisis ini digunakan untuk mengetahui variabel yang memiliki pengaruh paling dominan terhadap permitaan uang di Timor-leste.

6) Analisis kualitatif yaitu analisis yang digunakan sebagai penunjang analisis kuantitatif, analisis ini sifatnya melengkapi analisis kuantitatif.

\section{HASIL PENELITIAN DAN PEMBAHASAN}

\section{Gambaran Umum Bank Sentral Timor-Leste}

Bank Sentral adalah outoritas moniter Timor-Leste secara resmi didirikan pada tanggal 13 September 2011 oleh UU No. 5/2011, sesuai Konstitusi TimorLeste yang diatur dalam Pasal 143. Fungsi Bank Sentral sebelumnya dilakukan di Timor-Leste oleh Banking and Payments Authority (2001-2011) dan Central Payments Office (2000-2001) dan lembaga-lembaga ini diciptakan oleh Administrasi Transisi PBB di Timor-Leste ( UNTAET), yang mengelola negara dari Oktober 1999 sampai Mei 2002. Decree-Law No. 20/2003 mengatur mata uang resmi dolar America dan Centavos Timor-Leste menjadi uang resmi pemerintah Timor-Leste. Lembaga Negara yang mempunyai wewenang untuk memgeluarkan alat pembayaran yang sah dari suatu Negara, merumuskan dan malaksanakan kebijakan moneter, mengatur dan menjaga kelancaran sistem 
pembayaran, mengatur dan mengawasi perbankan serta menjalankan fungsi sebagai lender of the last resort.

Struktur BCTL terdiri dari empat Depatemen yang membawahi Governor dan dua wakil Governor dan satu Direktur Exekutif yaitu:

- Governor Bank Sentral bertanggung jawab langsung kepada, Departemen Administrasi, Divisi Ekonomi dan Statistik, Kontor khusus dukungan Hukum dan Kontor Internal Audit;

- Wakil Governor I bertanggung jawab kepada Departemen Pengawasan Sistem Keuangan (pengawasan perbankan), Devisi Indepeden, Anggaran dan Akuntansi;

- Wakil Governor II bertanggung jawab kepada Departement Pembayaran, Divisi Teknologi dan Informasi;

- Direktur Exekutif bertanggung jawab kepada Departemen Perminyakan (Petrolium Fund) Timor-Leste.

Kantor Pusat Bank Sentral perada di pusat ibu kota pemerintan Timor-Leste Dili tepatnya di jalan Ava Bispo Medeiros dekat Palácio do Governo. E-mail: www.bancocentral.tl BCTL mempunyai satu Kantor Cabang di OeCusse/Pantai Makasar di ibu Kota Distrit yang didirikan pada tanggal 10 Septemeber 2004, tepatnya di jalan Avenida António Taveiro Pante Makasar, Oe-Cusse.

\section{Deskripsi Variabel Penelitian}

Kebijakan pengendalian jumlah uang beredar harus dilakukan oleh bank sentral dan pemerintah melalui fiskal, mengingat terkait langsung dengan 
José Augusto Maria, I B. Panji Sedana, dan Luh Gede Sri Artini. Pengaruh Tingkat Suku...

pengendalian stabilitas ekonomi nasional. Perekonomian yang baik adalah perekonomian yang tidak terlalu fluktuatif.

Perkembangan angka-angka indicator makro di Timor-leste mengelami fluktuasi, dimana perkembangannya sangat dipengaruhi oleh kodisi ekonomi yang berlangung pada saat itu.

Variabel yang diperoleh dalam penelitian ini terdiri dari variabel jumlah uang yang beredar (Y) diproyeksikan uang beredar yang dioperasikan sebagai variabel dependen. Variavel tingkat suku bunga (X1), luja inflasi (X2) dan pertumbuhan ekonomi (X3) dioperasikan sebagai variabel independen. Sedangkan jumlah data yang digunakan dalam penelitian ini berjumlah 40 dan mengunakan data triwulan dari tahun $2004-2013$.

Hasil penelitian dapat dirumuskan bahwa variabel jumlah uang beredar (Y) memiliki rata-rata hitung (mean) sebesar 2.2604 artinya rata-rata jumlah uang beredar selama periode 2004 - 2013 adalah sebesar 226.04 juta dolar per tahun. Standar deviasi (simpangan baku) variavel jumlah uang beredar 0.26645 artinya selama triwulan pertama pengamatan, variabel uang beredar rata-rata sebesar 266.45 juta dolar.

Variabel suku bunga (X1) memiliki rata-rata hitung (mean) sebesar 1.7475 artinya rata-rata tingkat suku bunga selama periode 2004 - 2013 adalah sebesar 1.75 persen per tahun. Standar deviasi (simpangan baku) variabel suku bunga 0.65490 artinya selama triwulan pertama pengamatan, variabel suku bunga ratarata sebesar 0.65 persen per tahun. 
Variabel laju inflasi (X2) memiliki rata-rata hitung (mean) sebesar 7.7823 artinya rata-rata tingkat inflasi selama periode 2004 - 2013 adalah sebesar 7.78 persen per tahun. Standar deviasi variavel inflasi 4.01017 artinya selama triwulan pertama pengamatan, variabel inflasi rata-rata sebesar 4.01.

Variabel pertumbuhan ekonomi/GDP (X3) memiliki rata-rata hitung (mean) sebesar 214.3195 artinya rata-rata GDP selama periode 2004 - 2013 adalah sebesar 214.32 juta ribu dolar per tahun. Standar deviasi (simpangan baku) variabel GDP 54.83447 artinya selama triwulan pertama pengamatan, variabel GDP rata-rata sebesar 54.83 juta dolar.

Berdasarkan regresi hasil uji Regresi Berganda dan uji asumsi klasik yang meliputi uji normatitas, uji multikolinearitas, uji autokorelasi dan uji heteroskedastisitas dapat dilakukan pengujian hipotesis dalam penelitian ini yaitu sebagai berikut:

\section{Hipotesis Pertama}

Pengaruh tingkat suku bunga terhadap jumlah uang beredar sebesar -0.021 dengan signifikansi sebesar 0,753 yang berarti tingkat suku bunga memiliki pengaruh yang negatif signifikan terhadap Jumlah Uang Beredar. Artinya tingkat suku bunga semakin meningkat maka jumlah uang beredar akan menurun, karena masyarakat akan lebih tertarik menyimpan uangnya di bank untuk mendapat pendapatan yang lebih tinggi dengan tingkat suku bunga yang tinggi, sebalikanya tingkat suku bunga semakin menurun maka jumlah uang beredar akan meningkat, karena masyarakat akan menerik uangnya di bank untuk keperluan investasi dan konsumsi. 
José Augusto Maria, I B. Panji Sedana, dan Luh Gede Sri Artini. Pengaruh Tingkat Suku...

Analisis regresi menunjukkan bahwa tingkat suku bunga berpengaruh negatif terhadap jumlah uang beredar. Hasil analisis menunjukan nilai t hitung sebesar 0,317 dengan sig uji t 0,753. Artinya tingkat suku bunga tidak signifikan terhadap jumlah uang beredar.

\section{Hipotesis Kedua}

Pengaruh tingkat inflasi terhadap jumlah uang beredar sebesar -0.085 dengan signifikansi sebesar 0,029 yang berarti tingkat inflasi memiliki pengaruh yang negatif signifikan terhadap Jumlah Uang Beredar. Analisis pada uji asumsi klasik bahwa tingkat inflasi berpengaruh signifikan terhadap jumlah uang beredar. Hasil analisis menunjukan nilai t hitung sebesar -2,270 dengan sig uji t 0,029. Artinya laju inflasi berpengaruh negatif signifikan terhadap jumlah uang beredar. Artinya tingkat inflasi semakin menurun maka jumlah uang beredar akan menurun, karena Timor-Leste belum memiliki mata uang sendiri dan mengunakan mata uang dolar Amerika sehingga inflasi yang terjadi di Amerika akan berpengaruh negatif terhadap inflasi di Timor-Leste yang dapat juga berpengaruh menurunnya jumlah uang yang beredar. Hasil uji statistik menujukkan bahwa pada saat inflasi naik rata-rata dua digit yang tidak dapat dikendalikan pada saat krisis politik internal dan krisis keuangan global yang mempengaruhi kenaikan harga sebagian besar barang dan jasa, karena Timor-Leste mengunakan mata uang dolar Amerika yang menjadi mata uang bebas yang tidak dapat dikendalikan.

\section{Hipotesis Ketiga}

Pengaruh pertumbuhan GDP terhadap jumlah uang beredar sebesar -1.027 dengan signifikansi sebesar 0,000 yang berarti pertumbuhan GDP memiliki 
pengaruh yang positif signifikan terhadap Jumlah Uang Beredar. Artinya pertumbuhan GDP yang relatif tinggi akan menyebabkan meningkatnya pendapatan masyarakat sehingga jumlah uang beredar juga akan mengalami peningkatan, terutama untuk tujuan M1, sebalikanya pertumbuhan GDP relatif menurun maka jumlah uang beredar akan menurun, karena menurunnya pendapatan masyarakat.

Analisis pada uji asumsi klasik juga menunjukkan bahwa pertumbuhan GDP berpengaruh signifikan terhadap jumlah uang beredar.

Hasil analisis menunjukan nilai t hitung sebesar 15,644 dengan sig uji t 0,000. Artinya pertumbuhan GDP berpengaruh positif signifikan terhadap jumlah uang beredar. Hipotesis ketiga diterima.

\section{Pembahasan}

Dilihat dari hasil pembuktian hipotesis dan interpretasinya, maka akan dibahas terkait dengan teori-teori yang melandasi, penelitian-penelitian sebelumnya dan fakta-fakta empiris.

1) Berdasarkan kriteria goodness of fit, model yang dipergunakan memiliki hasil taksiran terbaik yaitu dengan nilai koefisien determinasi (R Square) 0.975 dengan probabilitas signifikansi nilai residual lebih besar dari 0,05 berarti terdistribusi dengan normal.

2) Berdasarkan kriteria pelanggaran asumsi klasik yang terdiri dari autokorelasi, multikolenieritas dan heteroskedastisitas, maka model ini menunjukkan bebas dari masalah pelanggaran asumsi klasik.

Secara lebih rinci hasil-hasil penaksiran tersebut selanjutnya akan dijabarkan berikut ini. 


\section{Analisis Determinasi}

Analisis deteminasi dengan mengunankan Model Linier Berganda ternyata memperoleh nilai koefisien determinasi (R Square) sebesar 0.975 artinya 99 persen variasi tingkat suku bunga, inflasi, GDP dan jumlah uang beredar satu tahun sebelumnya dapat menjelaskan variasi jumlah uang beredar periode $2004-$ 2013, sedangkan 1 persen lainnya dijelaskan oleh variasi variabel lain yang tidak dimasukkan dalam model analisis penelitian ini.

\section{Analisis regresi dari Estimasi Persamaan}

Nilai $\beta o=-221.168$ artinya apabila tingkat subu bunga, inflasi pertumbuhan GDP dan jumlah uang beredar satu tahun sebelumnya rendah sekali atau mendekati nol, maka rata-rata jumlah uang beredar elama periode 2004 2013 meningkat sebesar 221.168 milyar dolar. Artinya indikatorvariabelvariabel yang diangkat berpengaruh sangat besar terhadap jumlah uang beredar di Timor-Leste.

Nilai $\beta 1=-3.621$ artinya apabila tingkat suku bunga naik sebesar 1 persen maka jumlah uang beredar di Timor-Leste akan turun sebesar 3.621 milyar dolar dengan asumsi bahwa inflasi, pertumbuhan GDP dan jumlah uang beredar satu tahun sebelumnya konstan, namun uji statistik menunjukkan tidak berpengaruh signifikan pada taraf nyata 5 persen.

Nilai $\beta 2=-2.444$ artinya apabila tingkat inflasi naik sebesar 1 persen, maka jumlah uang beredar akan naik sebesar 2.444 milyar dolar dengan asumsi tingkat suku bunga, pertumbuhan GDP dan jumlah uang beredar satu tahun 
sebelumnya konstan. Hal ini menujukkan bahwa pada saat inflasi naik ratarata dua digit yang tidak dapat dikendalikan pada saat krisis politik internal dan krisis keuangan global yang mempengaruhi kenaikan harga sebagian besar barang dan jasa, karena Timor-Leste mengunakan mata uang dolar Amerika yang menjadi mata uang bebas yang tidak dapat dikendalikan.

Hasil uji statistik menunjukan bahwa tingkat inflasi semakin menurun maka jumlah uang beredar akan meningkat, karena Timor-Leste belum memiliki mata uang sendiri dan mengunakan mata uang dolar Amerika sehingga inflasi yang terjadi di Amerika akan berpengaruh negatif terhadap inflasi di Timor-Leste yang dapat mempengaruhi meningkatnya jumlah uang yang beredar.

Nilai $\beta 3=2.152$ artinya apabila pertumbuhan GDP naik sebesar 1 persen, maka jumlah uang beredar akan naik sebesar 2.152 milyar dolar dengan asumsi tingkat suku bunga, inflasi dan jumlah uang beredar satu tahun sebelumnya konstan.

\section{Implikasi Penelitian}

Hasil penelitian ini menunjukan bahwa suku bunga bank umum belum mampu memediasi inflasi dan pertumbuhan ekonomi untuk mempengaruhi jumlah uang beredar di Timor-Leste tahun 2004 - 2013. Pihak menajemen bank sentral mengambil tindakan kebijakan moneter sejalan dengan kebijakan fiskal pemerintah dalam mengedalikan jumlah uang beredar. Hal tersebut ditunjukan melalui kebijakan suku bunga bank umum agar mendorong pembangunan ekonomi yang akan berdanpak pada tertumbuhan ekonomi. Salah satu kegiatan 
tersebut melalui jalur bank umum dalam kegiatan memberikan jasa dalam lalu lintas pembayaran melalui jalur mikro kredit, pembiayaan proyek pemerintah serta melalui investor yang menanamkan modalnya untuk kematujuan pembangunan nasional.

Melalui penelitian ini dapat dilihat bahwa pihak manajemen Bank Sentral dan para stakeholder selalu mengaji lebih dalam tindakan yang terkait dengan kebijakan meneter dan keputusan dalam penempatan jumlah uang beredar. Tindakan tersebut akan mempegaruhi kinerja keuangan perbankan yang akhirnya akan menjadi bahan pertimbangan dan bahan evaluasi bagi pihak manajemen dan para stakeholder untuk melakukan keputusan strategis demi menjaga kelangsungan hidup Bank Sentral di masa medatang.

\section{SIMPULAN DAN SARAN}

\section{Simpulan}

Berdasarkan hasil penelitian dan pembahasan pada bab sebelumnya, maka dapat disimpulkan sebgai berikut:

1) Tingkat suku bunga bank umum berpengaruh negatif tidak signifikan terhadap jumlah uang beredar. Hal ini berarti meningkatnya suku bunga di Timor-Leste mampu menurunkan jumlah uang yang beredar.

2) Inflasi berpengaruh negatif signifikan terhadap jumlah uang yang beredar di Timor-Leste. Makin menurun inflasi, maka jumlah uang yang beredar akan semakin meningkat. Hal ini berarti Timor-Leste belum memiliki mata uang sendiri dan mengunakan mata uang dolar Amerika yang bebas beredar sehingga inflasi yang terjadi tidak terkendali yang berpengaruh negatif terhadap inflasi dan jumlah uang beredar di Timor-Leste. 
3) GDP berpengaruh positif signifikan terhadap jumlah uang yang beredar. Semakin tinggi GDP maka semakin banyak juga jumlah uang yang beredar Timor-Leste.

\section{Saran}

Berdasarkan hasil temuan dan kesimpulan penelitian, disarankan beberapa hal sebagai berikut:

1) Disarankan kepeda Bank Sentral, jika mengurangi jumlah uang yang beredar di Timor-Leste bisa dilakukan dengan meningkat suku bunga perbankan.

2) Disarankan kepada Bank Sentral, jika mengendalikan tingkat inflasi dan jumlah uang beredar bisa menciptakan mata uang sendiri sebagai uang resmi di Timor-Leste.

3) Penelitian ini terbatas hanya mengunakan suku bunga, inflasi, GDP sebagai variable yang berpengaruh terhadap jumlah uang yang beredar. Disarankan kepada penelitian selanjutnya menganalis diluar dari variable ini.

\section{REFERENSI}

Agus Widarjono, 2002, penelitian sebelumnya pengaruh GDP , Inflasi dan indeks harga konsumen berpengaruh jumlah uang yang beredar di Indonesia tahun $1990-2001$.

Akbar Maulana 2013, pada variabel penelitian yang merasa perlu memperhatikan jumlah uang beredar. Konsep uang beredar dapat ditinjau dari dua sisi, penawaran dan permintaan. Interaksi antara keduanya menentukan jumlah uang beredar dimasyarakat atau disebut stock mutual fund performance, interest rates, money supply, inflation: Jurnal Ilmu Manajemen 1 Nomor 3 Mei 2013 page 791. 
José Augusto Maria, I B. Panji Sedana, dan Luh Gede Sri Artini. Pengaruh Tingkat Suku...

Antonio Serra, 2013, Analisis ekonomi atas perkebangan ekonomi Timor-Leste di ASIA dan Pasific.

Banco Central de Timor-Leste, 2004 - 2013, Boletin Ekonomi dan Statistik atas pertumbuhan ekonomi Timor-Leste, bisa diakses melalui website: $\mathrm{tt}: / / \mathrm{www} \cdot$ boncocentral.tl.

Banco Central, 2004 - 2014, Data Statistik Banco Central de Timor-Leste (www.bancocentral.tl).

Bank Sentral Timor-Leste, Departemen Ekonomi dan statistik melakukan regular publikasi di Media dan Web page atas balance of payment yag dimuat tahunan dari tahun $2004-2013$.

Dasi Yunita, 2011, penelitian permodelan jumlah uang beredar mengunakan model regresi berganda, jurnal Ekponensial volume 2- numer 2 ISSN 2085 7824.

Dinnul Alfian Akbar 2012, hasil penelitian pengaruh kausalitas Inflasi, Tingkat Suku Bunga, dan Jumlah Uang Beredar: A Case of Indonesia Economy, Jurnal Ilmiah STIE MDP page 59.

Federal Reserve Bank of New York, annual report 2013, Ecoomic world reviews, vol 43. Pg. 143.

Gordon, 2000, Eight Edition, Macro Economic, United State: Addison Wesley Longman, Inc.

Hodge (2005), Jurnal Berjudul inflation and growth in south Africa bahwa inflasi menyebabkan penurunan pertumbuhan ekonomi dalam jangka pajang dan hubungan negatif antara inflasi dengan pertumbuhan ekonomi.

I Nyoman Nurcaya, 2014, Aplikasi Analisis Multivariate Dengan Program SPSS, Denpasar: Fakultas Ekonomi - Unud.

Insukindro,2003, kebijakan moneter yang tidak diantisipasi dan pengaruhnya terhadap komponen pasar uang di Indonesia. Makalah kongres ISEI ke XV di Batu Malang.

José Alexandre Xanana Gusmão 2010, determinan penawaran mata uang Dolar Amerika menjadi regim yang kuat dan mempenaruhi pengeluaran pemerintah, jumlah cadangan devisa dan besarnya pengganda uang terhadap jumlah uang beredar di Republik Demokrat Timot-Leste. IMF Journal 2010. 
Kuncoro, 2001, Metode Kuantatif, Teori dan Aplikasi untuk Bisnis dan Eknomi, Yogyakarta: UPP AMP YKPN.

Luh Kade Datrini 2009, Penelitian sebelumnya pengaruh suku bunga inflasi, pertumbuhan ekonomi dan krisi ekonomi terhadap jumlah uang yang beredar di Indonesia tahun 1992 - 2005.

Mantra, 2001, Langah-Langkah Penelitian Survai Usulan Penelitian dan Laporan Penelitian, Yogyakarta:BPFG-UGM.

Mervyn King (1996) dalam jurnalnya berjudul inflation how should central banks reduce inflation, mengatasi inflasi melalui kebijakan anti inflasi melalui kebijakan moneter.

Muhammad Tahir 2010, hasil penelitian dalam perdagangan bilateral secara signifikan berhubungan dengan GDP per kapita dalam organisasi Negaranegara berkembang di ASIA.

Nachrowi, 2002, Penggunaan Teknik Ekonometri, Jakarta : PT. Rajagrafindo Persada.

Nasution, 1998, Ekonomi Moneter, Jakarta: Penerbit Djambatan.

Nata Wirawan, 2001, Statistik 1 (Statistika Deskriptif) Untuk Ekonomi dan Bisnis, Denpasar : Keramas Emas.

Nguyen Huu Chau Duc, 2013, International Research Journal of Finance and Economics, analisis anggara dan Inflasi, Analisis Empiris pada ekonomi di Vietnam.

Ni Made Kusumawadhani 2012, pertumbuhan ekonomi suatu Negara dapat ditunjukkan dengan kenaikan nilai GDP. Besar kecilnya GDP dipengaruhi oleh berbagai factor, "C", "I", "G"dan net export. Fakultas MIPA-Unud, Jurnal Matematikan, Vol.1. No. 1, Agustus 2012, 99pg - 102pg.

Pemerintah Pusat Timor-Leste, 2013, APBN dan pertumbuhan ekonomi dari tahun ke tahun mulai $2004-2013$.

Program Pascasajana UNUD, 2013, Buku Pedoman Penulisan Usulan penelitian, Tesis, dan Desertasi, Denpasar. Universitas Udayana.

Putong, 2003, Ekonomi Mikro dan Makro, Jakarta: Ghalia Indonesia.

Santoso, Singgih. 2004. Buku Latihan SPSS Statistik Multivariate, Cetakan Ketiga, Jakarta : PT. Elex Media Komputindo Kelompok Gramedia. 
José Augusto Maria, I B. Panji Sedana, dan Luh Gede Sri Artini. Pengaruh Tingkat Suku...

Setyari, 2006, Analisis Berberapa Variabel Yang Mempengaruhi Posisi Fungsi Intermediasi Bank-Bank Umum Di Indonesia. Tesis Program Pasca Sarjana. Denpasar. FE UNUD, (tidak dipublikasikan).

Suparmoko, 2000, Pokok - Pokok Ekonomika, Edisi Pertama, Yoyakarta:BPFE atas penelitian laju inflasi dalam kenaikan harga umum secara terus menerus.

Suseno, 2005, Penyusunan Statistik Uang Beredar, Seri Kebanksentrala; 2.

Timor-Leste , 2013, Interest Rate Spread Wold Bank dan IMF (www.indexmundi.com).

Timor-Leste, 2013, Inflation dan GDP deflator (annual \%) in Timor Leste.

Timor-Leste, 2013, World Bank Indicators - Timor Leste - Exchange rates \& prices.

Widarjono, 2005, Ekonometrika Teori Dan Aplikasi Untuk Ekonomi dan Bisnis, Yogyakarta: Ekonisia FE. UII Yogyakarta.

Yustika Erani, 2007, Perekonomian Indonesia Satu Dekade Pasca krisis Ekonomi, Malang. BPFE. UNIBRAW. 